\title{
Array-CGH analysis in patients with intellectual disability and/or congenital malformations in Brazil
}

\author{
G.S. Vianna', P.F.V. Medeiros ${ }^{2}$, A.F. Alves ${ }^{2}$, T.O. Silva² and F.S. Jehee ${ }^{1}$ \\ ${ }^{1}$ Instituto de Ensino e Pesquisa da Santa Casa de Belo Horizonte, Belo Horizonte, \\ MG, Brasil \\ ${ }^{2}$ Universidade Federal de Campina Grande, Campina Grande, PB, Brasil \\ Corresponding author: F.S. Jehee \\ E-mail: fernanda@jehee.com.br \\ Genet. Mol. Res. 15 (1): gmr.15017769 \\ Received October 1, 2015 \\ Accepted November 18, 2015 \\ Published February 19, 2016 \\ DOI http://dx.doi.org/10.4238/gmr.15017769
}

ABSTRACT. In several patients, intellectual disability and/or congenital malformation may be attributed to chromosomal changes. In this study, we conducted an array-CGH test of 200 patients from the Northeast of Brazil with intellectual disability and/or congenital malformation. Blood samples were collected from the proband and from their parents when possible. DNA was extracted and investigated using the array-CGH test. Findings were evaluated for the pathogenicity in databases of benign and pathogenic changes (ISCA, UCSC, DGV, and DECIPHER). Forty-seven copy number variations (CNVs) were identified in $43 / 200$ (21.5\%) patients, including $25 / 98(25.5 \%)$ in males and 22/102 (21.57\%) in females. We considered 33 of these to be clinically significant, reaching a diagnosis rate of $16.5 \%$. The sizes of the CNVs varied from $102 \mathrm{~kb}$ to $24 \mathrm{Mb}$ in deletions and from 115 $\mathrm{kb}$ to $140 \mathrm{Mb}$ in duplications. In 10/47 (21.3\%) patients, the rearrangement involved a sex chromosome. Thirty-nine patients had one chromosomal aberration, while 2 concomitant abnormalities were detected in 4 patients. 
Ten of $47 \mathrm{CNVs}(21.3 \%)$ were $>5 \mathrm{Mb}$ in size. Fifteen patients had CNVs related to known syndromes. This research highlights the contribution of submicroscopic chromosomal changes to the etiology of intellectual disability and/or congenital malformation, particularly the implication of chromosomal abnormalities detected using an array-CGH test, with a high rate of $16.5 \%$. Thus, our results support the use of array-CGH replacing standard karyotype as the first-tier cytogenetic diagnostic test for patients with multiple congenital anomalies and/or intellectual disability.

Key words: Array-CGH; Congenital malformation; Intellectual disability; Northeastern Brazilian patients

\section{INTRODUCTION}

Epidemiological studies suggest that intellectual disability (ID) affects $2-3 \%$ of the general population worldwide and may occur with or without multiple congenital anomalies (MCA) (Rauch et al., 2006; Galasso et al., 2010; Pani et al., 2010; Ropers, 2010).

Over the past 50 years, conventional karyotyping has been successfully used to identify chromosomal abnormalities. Karyotype has the advantage of surveying the entire genome at once, but the resolution of cytogenetic analysis is limited to approximately 5-10 Mb. In the past 20 years, new molecular techniques have been introduced and smaller structural variations among submicroscopic changes so-called copy number variations (CNVs) can only be identified through molecular approaches, such as fluorescent in situ hybridization and multiplex ligation-dependent probe amplification and microarray techniques.

The microarray technique, introduced in 2003 to investigate genome-wide chromosome imbalances in patients with ID and/or MCA, can detect up to $99 \%$ of all chromosomal changes (Vissers et al., 2003; Hochstenbach et al., 2009).

Because of its high diagnostic yield, effectiveness and health-care possibilities, arraybased screen for CNVs was recommended in 2010 by the American College of Medical Genetics and Genomics as the preferred first clinical genetic diagnostic test for patients with developmental delay, ID or MCA (Newman et al., 2007; Wordsworth et al., 2007; Gijsbers et al., 2009; Manning et al., 2010; Miller et al., 2010; Regier et al., 2010; South and Brothman, 2011; Bartnik et al., 2014) . In addition, microarray analyses provide accurate diagnosis in approximately twice as many cases as classical karyotyping and fluorescent in situ hybridization (Gijsbers et al., 2009; Hochstenbach et al., 2009; Ahn et al., 2010; Miller et al., 2010). In recent years, approximately $15-20 \%$ of ID cases are caused by submicroscopic CNVs (Zahir and Friedman, 2007; Gijsbers et al., 2009).

In Brazilian studies, genome changes investigated by array techniques have been detected in up to $25 \%$ of patients with idiopathic syndromic ID (Krepischi-Santos et al., 2006; Hochstenbach et al., 2011).

Here, we present a pioneering study of array-CGH in a group of Northeastern Brazilian patients with ID and/or MCA with no etiological diagnosis.

\section{MATERIAL AND METHODS}

From April 2010 to July 2014, a total of 200 patients were referred for genetic diagnosis by medical genetic centers from the Northeastern states of Brazil. Our total group consisted of 
98 (49\%) males and 102 (51\%) females. Inclusion criterion was ID without a defined etiology, associated or not with MCAs.

\section{Sample collection and DNA extraction}

Blood samples were collected from the patients and their parents, when available. DNA was extracted from peripheral blood leukocytes using a salting-out method according to standard protocols.

\section{Array-CGH}

Investigation was performed using array-CGH with $44 \mathrm{~K}(\mathrm{~N}=1), 60 \mathrm{~K}(\mathrm{~N}=180)$, and 180 $\mathrm{K}(\mathrm{N}=19)$ oligo-chips (Agilent Technologies, Santa Clara, CA, USA). DNA digestion, labeling, and hybridization were performed following the manufacturer instructions.

\section{Analysis and CNV classification}

All chromosomal abnormalities identified, including deletions and duplications of at least 3 adjacent probes or of a minimum region of $300 \mathrm{~kb}$, were compared with genomic variants described in databases of benign and pathogenic changes to define their possible pathogenicity (DGV http:// projects.tcag.ca/variation/, UCSC Genome Browser http://www.genome.ucsc.edu/, ISCA https:// www.iscaconsortium.org/, and DECIPHER http://decipher.sanger.ac.uk/). Furthermore, gene content was also evaluated using databases such as the NCBI Gene Database, GeneCards, and OMIM.

CNVs were classified as described by Miller et al. (2010) and were classified into 4 groups: I) causatives, when associated with known microdeletion/microduplication syndromes; II) probably causative, when the CNV was not previously associated with known microdeletion/microduplication syndromes, but contained genes known to cause a syndrome of a clear phenotype (Ahn et al., 2013) or because similar CNVs were already described in patients from other studies; III) noncausative (benign); IV) VOUS, variants of unknown clinical significance.

\section{RESULTS}

Samples from 200 children with ID and/or MCA were analyzed. CNVs were identified in 43/200 (21.5\%) patients (Figure 1); 25/98 (25.5\%) males and 22/102 (21.57\%) females. The CNVs included a total of 27 deletions and 20 duplications. In 10/47 (21.3\%) patients, the rearrangement involved a sex chromosome. Thirty-nine patients $(19.5 \%)$ had a chromosomal aberration, whereas 2 concomitant abnormalities (i.e., 1 duplication and 1 deletion) were detected in 4 patients $(2 \%)$. Ten of $47 \mathrm{CNVs}(21.3 \%)$ were $>5 \mathrm{Mb}$ in size.

A total of 33 causative or probably causative CNVs were detected (16.5\%). Among these, microdeletion/microduplications related to known syndromes were identified in 15 patients (7.5\%). These syndromes included: chromosome 16p11.2 deletion syndrome; Miller-Dieker lissencephaly syndrome; chromosome 14q11-q22 deletion syndrome; CHARGE syndrome; chromosome 1q41-q42 deletion syndrome; Williams-Beuren syndrome (two 2 cases); Ritscher-Schinzel syndrome; chromosome 7q11.23 duplication syndrome; chromosome 15q13.3 deletion syndrome; Wolf-Hirschhorn syndrome; neurofibromatosis; ichthyosis; and Klinefelter syndrome (Table 1). 


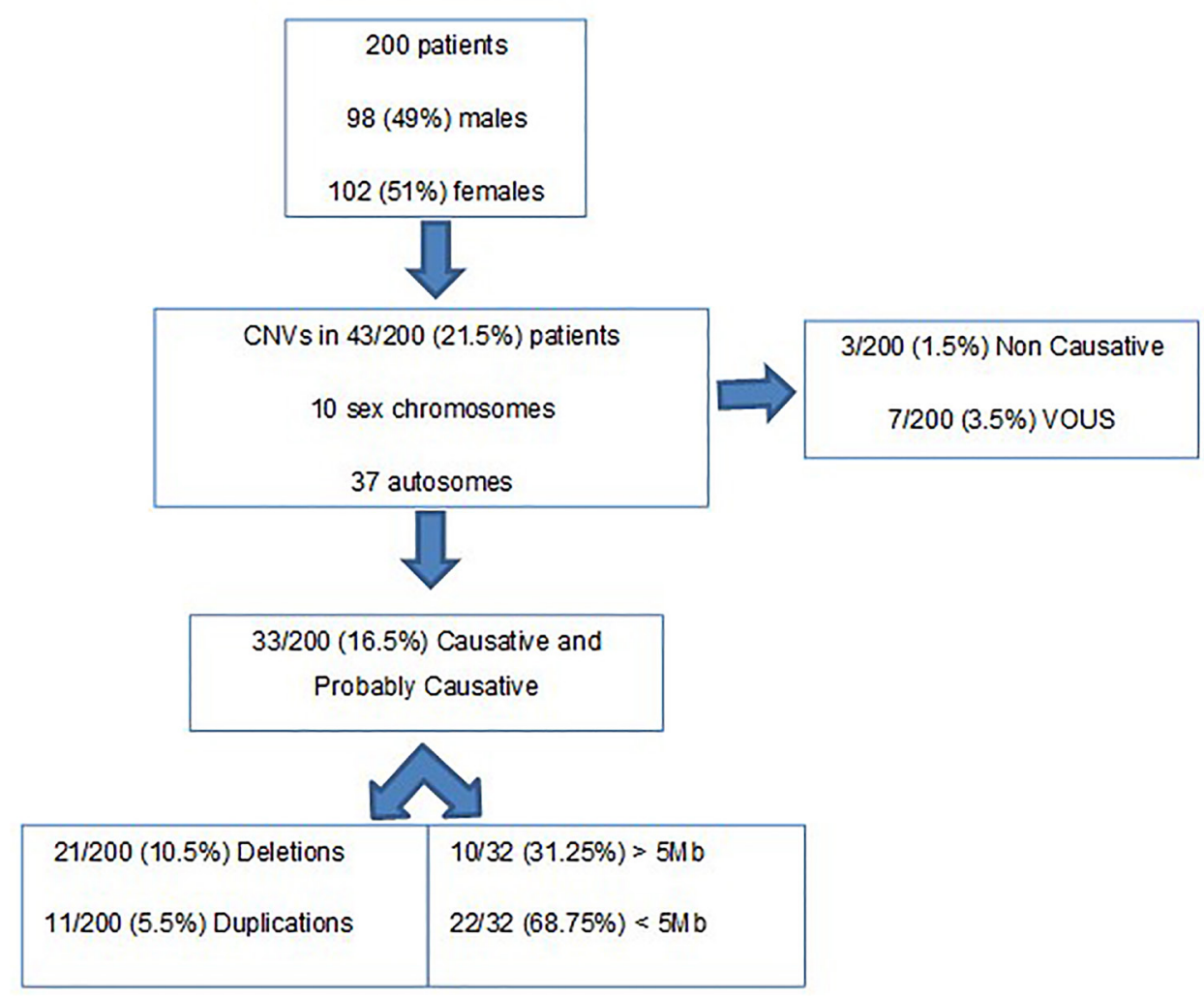

Figure 1. Flow diagram showing the number of patients studied and their respective CNVs.

Table 1. Array-CGH results of 15 Brazilian patients with causative CNVs associated with known microdeletion/ microduplication syndromes (group I).

\begin{tabular}{|c|c|c|c|c|c|}
\hline Patient & Gender & Resolution & Locus (Hg 18) & Size & Associated syndrome/OMIM \\
\hline 1 & $\mathrm{M}$ & $60 \mathrm{k}$ & array 1q41q42 (221.105.086-222.351.150)x1 & $1.3 \mathrm{Mb}$ & 1q41q42 Deletion syndrome (MIM ID \#612530) \\
\hline 2 & $\mathrm{~F}$ & $60 \mathrm{k}$ & $\begin{array}{l}\text { array 4p16.3-p16.1 (62.320-6.698.980)x1/array } \\
12 \mathrm{p} 13.33-\mathrm{p} 13.32(100.698-10.177 .433) \times 3\end{array}$ & $6.6 \mathrm{Mb} / 10 \mathrm{Mb}$ & Wolf- Hirschhorn syndrome (MIM ID \#194190) \\
\hline 3 & $\mathrm{~F}$ & $60 \mathrm{k}$ & array $7 \mathrm{q} 11.23(72.652 .411-74.136 .224) \times 1$ & $1.5 \mathrm{Mb}$ & Williams-Beuren syndrome (MIM ID \#194050) \\
\hline 4 & $\mathrm{~F}$ & $60 \mathrm{k}$ & array $7 \mathrm{q} 11.23(72.404 .248-73.831 .333) \times 1$ & $1.4 \mathrm{Mb}$ & Williams-Beuren syndrome (MIM ID \#194050) \\
\hline 5 & $\mathrm{M}$ & $60 \mathrm{k}$ & array $7 \mathrm{q} 11.23(72.382 .783-73.777 .467) \times 3$ & $1.5 \mathrm{Mb}$ & 7q11.23 Duplication syndrome (MIM ID \#609757) \\
\hline 6 & $\mathrm{~F}$ & $60 \mathrm{k}$ & array $8 \mathrm{q} 12.1-\mathrm{q} 12.2(61.282 .418-61.831 .475) \times 1$ & $549 \mathrm{~kb}$ & CHARGE syndrome (MIM ID \#214800) \\
\hline 7 & $\mathrm{~F}$ & $180 \mathrm{k}$ & array 8q24.13 (126.051.391-126.389.649)x3 & $338 \mathrm{~kb}$ & Ritscher-Schinzel syndrome (MIM ID \#220210) \\
\hline 8 & $\mathrm{M}$ & $60 \mathrm{k}$ & array $14 \mathrm{q} 12-\mathrm{q} 13.3(31.097 .626-36.478 .503) \times 1$ & $5.4 \mathrm{Mb}$ & 14q11-q22 Deletion syndrome (MIM ID \#613457) \\
\hline 9 & $\mathrm{M}$ & $60 \mathrm{k}$ & array 15q13.2-q13.3 (28.742.018-30.231.385)x1 & $1.48 \mathrm{Mb}$ & 15q13.3 Microdeletion syndrome (MIM ID \#612001) \\
\hline 10 & $\mathrm{~F}$ & $60 \mathrm{k}$ & array 16p11.2 (29.581.468-30.098.094)x1 & $500 \mathrm{~kb}$ & 16p11.2 Deletion syndrome (MIM ID \#611913) \\
\hline 11 & M & $60 \mathrm{k}$ & $\begin{array}{l}\text { array 2q13 (110.219.763-110.322.064)x1/ } \\
\text { array } 17 \mathrm{p} 13.3(867.382-1.592 .841) \times 1\end{array}$ & $725 \mathrm{~kb} / 102 \mathrm{~kb}$ & Miller-Dieker syndrome (MIM ID \#247200) \\
\hline 12 & $\mathrm{M}$ & $60 \mathrm{k}$ & array 16p12.1 (21.907.260-22.315.593)x1 & $\sim 400 \mathrm{~kb}$ & Recurrent 16p12.1 microdeletion (MIM ID \#136570) \\
\hline 13 & $\mathrm{M}$ & $60 \mathrm{k}$ & array $17 q 11.2(26.057 .789-27.351 .206) \times 1$ & $\sim 1.3 \mathrm{Mb}$ & Neurofibromatosis (MIM ID \#162200) \\
\hline 14 & M & $60 \mathrm{k}$ & $\begin{array}{l}\text { array Xp22.31(110.777.959-111.374.876)x1/ } \\
\text { array } 7 q 31.1(110777959-111374876) \times 1\end{array}$ & $\sim 1.5 \mathrm{Mb} / 700 \mathrm{~kb}$ & Ichthyosis (MIM ID \#308100) \\
\hline 15 & $\mathrm{M}$ & $60 \mathrm{k}$ & array Xp22.33-q28 (701-154.832.671)x2 & $\mathrm{XXY}$ & Klinefelter syndrome (MIM ID \#312300) \\
\hline
\end{tabular}

In 18 patients $(9 \%)$, we detected probably causative CNVs that had not previously been associated with any known syndrome (Table 2). 
Table 2. Array-CGH results of 18 Brazilian patients with probably-causative CNVs, not previously associated with known microdeletion/microduplication syndromes (group II).

\begin{tabular}{|c|c|c|c|c|}
\hline Patient & Gender & Resolution & Locus ( $\mathrm{Hg} \mathrm{18)}$ & Size \\
\hline 16 & $\mathrm{~F}$ & $44 \mathrm{k}$ & array $2 \mathrm{p} 25.3(20.141-2.071 .858) \times 1$ & $\sim 2 \mathrm{Mb}$ \\
\hline 17 & M & $60 \mathrm{k}$ & array 7q21.11 (79.320.563-84.313.060)x1 & $4.9 \mathrm{Mb}$ \\
\hline 18 & $\mathrm{M}$ & $60 \mathrm{k}$ & array $9 \mathrm{q} 34.11(130.097 .894-132.378 .474) \times 1$ & $2.2 \mathrm{Mb}$ \\
\hline 19 & $\mathrm{M}$ & $60 \mathrm{k}$ & array $11 \mathrm{q} 13.1(63.365 .945-64.625 .636) \times 1$ & $\sim 1.27 \mathrm{Mb}$ \\
\hline 20 & $\mathrm{~F}$ & $60 \mathrm{k}$ & array 13q21.33-q22.3 (67.907.119-77.776.997)x1 & $9.8 \mathrm{Mb}$ \\
\hline 21 & $\mathrm{~F}$ & $180 \mathrm{k}$ & array $14 q 32.31-q 32.33(102.717 .528-107.287 .649) \times 3$ & $4.5 \mathrm{Mb}$ \\
\hline 22 & $\mathrm{~F}$ & $60 \mathrm{k}$ & array $15 \mathrm{q} 11.2-\mathrm{q} 13.1(18.946 .017-26.830 .949) \times 3$ & $8 \mathrm{Mb}$ \\
\hline 23 & $\mathrm{~F}$ & $60 \mathrm{k}$ & array $15 \mathrm{q} 26.3(97.606 .456-100.201 .002) \times 1$ & $2.6 \mathrm{Mb}$ \\
\hline 24 & $\mathrm{M}$ & $60 \mathrm{k}$ & array 16q11.2-q22.3 (45.058.116-70.424.463)x3 & $25 \mathrm{Mb}$ \\
\hline 25 & $\mathrm{~F}$ & $60 \mathrm{k}$ & array $17 \mathrm{p} 13.3(2.340 .484-2.516 .432) \times 1$ & $175 \mathrm{~kb}$ \\
\hline 26 & $\mathrm{M}$ & $60 \mathrm{k}$ & array $18 \mathrm{p} 11.32-\mathrm{p} 11.21(145.520-14.071 .934) \times 1$ & $13.9 \mathrm{Mb}$ \\
\hline 27 & $\mathrm{M}$ & $60 \mathrm{k}$ & array $18 \mathrm{q} 21.2-\mathrm{q} 23(51.915 .019-76.083 .258) \times 1$ & $\sim 24 \mathrm{Mb}$ \\
\hline 28 & $\mathrm{~F}$ & $60 \mathrm{k}$ & array $18 \mathrm{q} 12.3-\mathrm{q} 22(38.288 .660-67.206 .375) \times 3$ & $\sim 30 \mathrm{Mb}$ \\
\hline 29 & $\mathrm{~F}$ & $60 \mathrm{k}$ & array $22 \mathrm{q} 11.22-11.23(21.386 .362-23.318 .602) \times 3$ & $\sim 1.9 \mathrm{Mb}$ \\
\hline 30 & M & $60 \mathrm{k}$ & array Xq13.2-q13.3 (73.422.371-74.266.467)×2 & $\sim 800 \mathrm{~kb}$ \\
\hline 31 & $\mathrm{M}$ & $60 \mathrm{k}$ & array Xq24 (118.593.371-118.725.211)x1 & $130 \mathrm{~kb}$ \\
\hline 32 & $\mathrm{M}$ & $60 \mathrm{k}$ & array Xp22.31 (8.393.893-8.649.904)x2 & $\sim 250 \mathrm{~kb}$ \\
\hline 33 & $\mathrm{~F}$ & $60 \mathrm{k}$ & array Xq27.2-q28 (140.565.997-154.886.088)x1/ array Xp22.33-q27. (701-140.385.067)x 3 & $14 \mathrm{Mb} / 140 \mathrm{Mb}$ \\
\hline
\end{tabular}

\section{DISCUSSION}

Several studies have shown that it is essential for patients with ID and/or MCA to obtain a definitive diagnosis to receive early medical interventions, better clinical management (Coulter et al., 2011; Riggs et al., 2014), and proper genetic counseling (Pina-Neto, 2008).

In this study, we identified CNVs in 43 of 200 patients (21.5\%), 33 of which were considered to be clinically significant, bringing the causative diagnosis rate to $16.5 \%$.

This is the first report of a group of patients from Northeastern Brazil with ID and/or MCA using array-CGH to detect CNVs. Although the selection criteria for array-CGH investigations are highly variable, similar reports in the Brazilian population showed approximately the same detection rate of pathological CNVs. Among 95 Brazilian syndromic patients, Krepischi-Santos et al. (2006) accounted for $17 \%$ of CNVs to be causally related to abnormal phenotypes. Pereira et al. (2014) detected $22 \%$ of pathogenic CNVs in 15 patients from Central Brazil who had IDs.

In our study, among the 33 causative and probably causative CNVs (Tables 1 and 2), only 8 patients (4\%), who had CNVs larger than $5 \mathrm{Mb}$ that could have been detected by karyotype, had this test been offered previously. Thus, the remaining 25 patients would be undiagnosed after conventional cytogenetics, indicating the major contribution of array-CGH for diagnosing these patients.

Interestingly, Klinefelter syndrome was not clinically suspected. This patient was referred at 10 years old, in the prepubertal stage, when hypogonadism had not been characterized. Although his height was in 90th percentile, the parents complained of poor school performance, attention deficit hyperactivity disorder, and bipolar disorder. In this scenario, Klinefelter syndrome was not clinically suspected. Because of the patient's age, it was not possible to diagnose hypogonadism. The unique features related to Klinefelter observed in this patient were height in the 90th percentile and poor school performance. The main feature of this patient was ID and psychiatric disorder.

Patient 33 had a karyotype revealing an extra rearranged $X$ chromosome, suggesting a 47,XXX. However, the clinical phenotype was not completely compatible with the described features of triple $X$ females (Butnariu et al., 2013). The array-CGH test was essential for defining the break points and showed that although she indeed had 3 copies of SHOX (Xp22.33), which may explain her high stature $(180 \mathrm{~cm})$, she had only 1 copy of FOP1 (Xq28), a gene related to premature ovarian failure, which may have caused her hypogonadism hypogonadotropic (Rosa et al., 2008). 
Eighteen CNVs were classified as probably causative (Table 2). Although they are not related to any previously described syndrome, typically a gene within the CNV is related to a similar phenotype. For example, patient 25 showed a 175-kb interstitial deletion in 17p13.3, which only covers the LIS1 gene (MIM ID \#601545). This likely explains the patient's clinical phenotype (Dobyns et al., 1993; Neer et al., 1993). Patient 31 showed a 130-kb interstitial deletion in Xq24, to which UBE2A is mapped (MIM ID \#312180). Genomic deletions or point mutations in UBE2A have been described in individuals with ID and dysmorphic facial features (Budny et al., 2010). Patient 32 showed a 250-kb interstitial duplication in Xq22.31 involving KAL1 (MIM ID \#300836), which causes ID and MCA in patients when duplicated (Sowińska-Seidler et al., 2015).

Some CNVs were also classified as probably causative because they have been described in other patients with similar clinical characteristics. For example, patients 16, 21, and 24 had a terminal deletion at 2p25.3 (Stevens et al., 2011; Bonaglia et al., 2014; Doco-Fenzy et al., 2014), a terminal duplication at 14q32.31-q32.33, and an interstitial deletion of $500 \mathrm{~kb}$ at $16 \mathrm{p} 11.2$, respectively.

Among the CNVs classified as causative $(\mathrm{N}=33)$, a greater number of deletions than duplications (22 vs 11) was observed. As previously described by Menten et al. (2006), this observation can be explained in a few ways: there is a greater chance that some duplications are missed technically, duplications generally cause a milder phenotype leading to a selection bias, and the biological frequency of a deletion event is higher than that of a duplication event. Similarly, at the chromosomal level, chromosomal trisomies or supernumerary marker chromosomes are better tolerated than autosomal monosomies (Liehr et al., 2011).

CNVs detected in patients 34,35 , and 36 were classified as non-causative (Table 3) because there have been several descriptions of other patients with variations in the same chromosomal segment in databases, and in some cases, the variations were inherited from a normal parent.

Table 3. Array-CGH results of the 3 Brazilian patients with non-causative CNVs - benign (group III)

\begin{tabular}{l|c|l|l|c}
\hline Patient & Gender & Resolution & Locus $(\mathrm{Hg} 18) /$ inheritance & Size \\
\hline 34 & $\mathrm{~F}$ & $60 \mathrm{k}$ & array $6 \mathrm{q} 11.1(62.354 .703-62.935 .334) \times 3 / \mathrm{mat}$ & $\sim 1 \mathrm{Mb}$ \\
\hline 35 & $\mathrm{~F}$ & $60 \mathrm{k}$ & array $9 \mathrm{p} 24.3(194.090-371.572) \times 3 / \mathrm{mat}$ & $177 \mathrm{~kb}$ \\
\hline 36 & $\mathrm{M}$ & $60 \mathrm{k}$ & array $15 \mathrm{q} 26.3(99.753 .088-100.080 .964) \times 3 / \mathrm{mat}$ & $\sim 480 \mathrm{~kb}$ \\
\hline
\end{tabular}

For instance, DOCK8 (MIM ID \#611432) maps within the 177-kb interstitial duplication in 9p24.3 in patient 35. While deletions of the same region have been described in patients with ID (Griggs et al., 2008; Di Gregorio et al., 2014), the effect of duplication of DOCK8 has not been elucidated. Mental disabilities have been described in patients with duplications in the same genomic segment, but in all cases the duplication was inherited from an unaffected parent. Furthermore, the DGV database reports the occurrence of duplication in this segment in individuals in the general population. Therefore, this variant may contribute to the patient's clinical status; however, the presence of the variant in an unaffected individual clearly indicates that this finding is not sufficient to explain the clinical manifestations, and thus this CNV was classified as not-causative.

Seven CNVs (3.5\%) were classified as VOUS (Table 4) because literature data or inheritance patterns did not enable clear determination of its pathogenicity. Patient 37 showed a terminal deletion in the short arm of chromosome 4, affecting band 4p16. Although this CNV overlaps with the region associated with Wolf-Hirschhorn syndrome, it is smaller than that reported in patients with the syndrome and does not appear to involve the critical region. There have been no 
descriptions of patients with deletions involving only PDE6B, as was observed in this patient. This girl has IDs but she did not have the typical facial characteristics associated with Wolf-Hirschhorn syndrome.

Table 4. Array-CGH results of the six Brazilian patients with variants of unknown clinical significance (VOUS; group IV).

\begin{tabular}{|c|c|c|c|c|}
\hline Patient & Gender & Resolution & Locus (Hg 18)/inheritance & Size \\
\hline 37 & $\mathrm{~F}$ & $60 \mathrm{k}$ & array $4 \mathrm{p} 16(61.352-799.952) \times 1 /$ indeterminate & $\sim 800 \mathrm{~kb}$ \\
\hline 38 & $\mathrm{~F}$ & $60 \mathrm{k}$ & array 11q24.2 (126.467.319-126.699.302)x3/indeterminate & $231 \mathrm{~kb}$ \\
\hline 39 & $\mathrm{~F}$ & $60 \mathrm{k}$ & array $16 \mathrm{p} 13.11(15.399 .618-15.514 .494) \times 3 /$ indeterminate & $115 \mathrm{~kb}$ \\
\hline 40 & $\mathrm{~F}$ & $60 \mathrm{k}$ & array $19 \mathrm{p} 13.3-\mathrm{p} 13.12(13.471 .747-14.684 .081) \times 1 /$ indeterminate & $1.2 \mathrm{Mb}$ \\
\hline 41 & $\mathrm{~F}$ & $180 \mathrm{k}$ & array Xq21.1 (80.364.877-80.653.581) $\times 3 /$ indeterminate & $289 \mathrm{~kb}$ \\
\hline 42 & M & $60 \mathrm{k}$ & array Xp22.31 (7.594.433-8.057.652)x2/indeterminate & $\sim 500 \mathrm{~kb}$ \\
\hline 43 & $\mathrm{M}$ & $60 \mathrm{k}$ & array Xp22.31 (6.462.695-8.057.511)x2/indeterminate & $\sim 1.6 \mathrm{Mb}$ \\
\hline
\end{tabular}

Patient 43 contained a duplication of $\sim 1.6 \mathrm{Mb}$ in Xp22.31, as reported in another patient by Faletra et al. (2012). Similarly, variants were observed both in normal individuals and in individuals with clinical conditions associated with ID. Several of the affected individuals inherited the variant from normal parents, showing that this duplication alone is not sufficient to cause the clinical condition, but may determine a predisposition to it.

Although modern molecular cytogenetic methods, including array-CGH, show great potential for identifying novel chromosomal syndromes, there are still several diagnostic challenges and unexplored questions, particularly regarding the role of CNVs in the pathogenesis of complex human genetic diseases. Variants of uncertain clinical significance should be reviewed periodically. Thus, with the description of new cases with the same CNV, it will be possible to elucidate the relationships between the variant and the patient's condition.

A high percentage of ID and MCA are caused by submicroscopic chromosomal imbalances.

Microarray molecular screening of the whole genome is increasingly thought to have clinical impact, replacing standard karyotyping as the first-tier cytogenetic diagnostic test. This may help families and their assistant physicians in reaching an accurate diagnosis, bringing closure to their postnatal search for an explanation regarding the ID and/or MCA.

\section{Conflicts of interest}

The authors declare no conflict of interest.

\section{ACKNOWLEDGMENTS}

Research supported by Fundação de Amparo à Pesquisa de Minas Gerais/FAPEMIG; Coordenação de Aperfeiçoamento de Pessoal de Nível Superior/CAPES; Conselho Nacional de Desenvolvimento Científico e Tecnológico/CNPq; and Instituto de Ensino e Pesquisa da Santa Casa de Belo Horizonte/IEP-SCBH.

\section{REFERENCES}

Ahn JW, Bint S, Bergbaum A, Mann K, et al. (2013). Array CGH as a first line diagnostic test in place of karyotyping for postnatal referrals - results from four years' clinical application for over 8,700 patients. Mol. Cytogenet. 6: 16. http://dx.doi. org/10.1186/1755-8166-6-16 
Ahn JW, Mann K, Walsh S, Shehab M, et al. (2010). Validation and implementation of array comparative genomic hybridisation as a first line test in place of postnatal karyotyping for genome imbalance. Mol. Cytogenet. 3: 9. http://dx.doi. org/10.1186/1755-8166-3-9

Bartnik M, Nowakowska B, Derwińska K, Wiśniowiecka-Kowalnik B, et al. (2014). Application of array comparative genomic hybridization in 256 patients with developmental delay or intellectual disability. J. Appl. Genet. 55: 125-144. http://dx.doi. org/10.1007/s13353-013-0181-x

Bonaglia MC, Giorda R and Zanini S (2014). A new patient with a terminal de novo 2p25.3 deletion of $1.9 \mathrm{Mb}$ associated with early-onset of obesity, intellectual disabilities and hyperkinetic disorder. Mol. Cytogenet. 7: 53. http://dx.doi. org/10.1186/1755-8166-7-53

Budny B, Badura-Stronka M, Materna-Kiryluk A, Tzschach A, et al. (2010). Novel missense mutations in the ubiquitinationrelated gene UBE2A cause a recognizable X-linked mental retardation syndrome. Clin. Genet. 77: 541-551. http://dx.doi. org/10.1111/j.1399-0004.2010.01429.x

Butnariu L, Rusu C, Caba L, Pânzaru M, et al. (2013). Genotype- phenotype correlation in trisomy X: a retrospective study of a selected group of 36 patients and review of literature. Rev. Med. Chir. Soc. Med. Nat. lasi 117: 714-721.

Coulter ME, Miller DT, Harris DJ, Hawley P, et al. (2011). Chromosomal microarray testing influences medical management. Genet. Med. 13: 770-776. http://dx.doi.org/10.1097/GIM.0b013e31821dd54a

Di Gregorio E, Savin E, Biamino E, Belligni EF, et al. (2014). Large cryptic genomic rearrangements with apparently normal karyotypes detected by array-CGH. Mol. Cytogenet. 7: 82. http://dx.doi.org/10.1186/s13039-014-0082-7

Dobyns WB, Reiner O, Carrozzo R and Ledbetter DH (1993). Lissencephaly. A human brain malformation associated with deletion of the LIS1 gene located at chromosome 17p13. JAMA 270: 2838-2842. http://dx.doi.org/10.1001/ jama.1993.03510230076039

Doco-Fenzy M, Leroy C, Schneider A, Petit F, et al. (2014). Early-onset obesity and paternal 2pter deletion encompassing the ACP1, TMEM18, and MYT1L genes. Eur. J. Hum. Genet. 22: 471-479. http://dx.doi.org/10.1038/ejhg.2013.189

Faletra F, D'Adamo AP, Santa Rocca M, Carrozzi M, et al. (2012). Does the 1.5 Mb microduplication in chromosome band Xp22.31 have a pathogenetic role? New contribution and a review of the literature. Am. J. Med. Genet. A. 158A: 461-464. http://dx.doi.org/10.1002/ajmg.a.34398

Galasso C, Lo-Castro A, El-Malhany N and Curatolo P (2010). "Idiopathic" mental retardation and new chromosomal abnormalities. Ital. J. Pediatr. 36: 17. http://dx.doi.org/10.1186/1824-7288-36-17

Gijsbers AC, Lew JY, Bosch CA, Schuurs-Hoeijmakers JH, et al. (2009). A new diagnostic workflow for patients with mental retardation and/or multiple congenital abnormalities: test arrays first. Eur. J. Hum. Genet. 17: 1394-1402. http://dx.doi. org/10.1038/ejhg.2009.74

Griggs BL, Ladd S, Saul RA, DuPont BR, et al. (2008). Dedicator of cytokinesis 8 is disrupted in two patients with mental retardation and developmental disabilities. Genomics 91: 195-202. http://dx.doi.org/10.1016/j.ygeno.2007.10.011

Hochstenbach R, van Binsbergen E, Engelen J, Nieuwint A, et al. (2009). Array analysis and karyotyping: workflow consequences based on a retrospective study of 36,325 patients with idiopathic developmental delay in the Netherlands. Eur. J. Med. Genet. 52: 161-169. http://dx.doi.org/10.1016/j.ejmg.2009.03.015

Hochstenbach R, Buizer-Voskamp JE, Vorstman JA and Ophoff RA (2011). Genome arrays for the detection of copy number variations in idiopathic mental retardation, idiopathic generalized epilepsy and neuropsychiatric disorders: lessons for diagnostic workflow and research. Cytogenet. Genome Res. 135: 174-202. http://dx.doi.org/10.1159/000332928

Krepischi-Santos AC, Vianna-Morgante AM, Jehee FS, Passos-Bueno MR, et al. (2006). Whole-genome array-CGH screening in undiagnosed syndromic patients: old syndromes revisited and new alterations. Cytogenet. Genome Res. 115: $254-261$. http://dx.doi.org/10.1159/000095922

Liehr T, Ewers E, Hamid AB, Kosyakova N, et al. (2011). Small supernumerary marker chromosomes and uniparental disomy have a story to tell. J. Histochem. Cytochem. 59: 842-848. http://dx.doi.org/10.1369/0022155411412780

Manning $M$ and Hudgins L; Professional Practice and Guidelines Committee (2010). Array-based technology and recommendations for utilization in medical genetics practice for detection of chromosomal abnormalities. Genet. Med. 12: 742-745. http://dx.doi.org/10.1097/GIM.0b013e3181f8baad

Menten B, Maas N, Thienpont B, Buysse K, et al. (2006). Emerging patterns of cryptic chromosomal imbalance in patients with idiopathic mental retardation and multiple congenital anomalies: a new series of 140 patients and review of published reports. J. Med. Genet. 43: 625-633. http://dx.doi.org/10.1136/jmg.2005.039453

Miller DT, Adam MP, Aradhya S, Biesecker LG, et al. (2010). Consensus statement: chromosomal microarray is a first-tier clinical diagnostic test for individuals with developmental disabilities or congenital anomalies. Am. J. Hum. Genet. 86: 749-764. http://dx.doi.org/10.1016/j.ajhg.2010.04.006

Neer EJ, Schmidt CJ and Smith T (1993). LIS is more. Nat. Genet. 5: 3-4. http://dx.doi.org/10.1038/ng0993-3

Newman WG, Hamilton S, Ayres J, Sanghera N, et al. (2007). Array comparative genomic hybridization for diagnosis of 
developmental delay: an exploratory cost-consequences analysis. Clin. Genet. 71: 254-259. http://dx.doi.org/10.1111/ j.1399-0004.2007.00756.x

Pani AM, Hobart HH, Morris CA, Mervis CB, et al. (2010). Genome rearrangements detected by SNP microarrays in individuals with intellectual disability referred with possible Williams syndrome. PLoS One 5: e12349. http://dx.doi.org/10.1371/ journal.pone.0012349

Pereira RR, Pinto IP, Minasi LB, de Melo AV, et al. (2014). Screening for intellectual disability using high-resolution CMA technology in a retrospective cohort from Central Brazil. PLoS One 9: e103117. http://dx.doi.org/10.1371/journal. pone.0103117

Pina-Neto JM (2008). Genetic counseling. J. Pediatr. (Rio J.) 84 (Suppl): S20-S26.

Rauch A, Hoyer J, Guth S, Zweier C, et al. (2006). Diagnostic yield of various genetic approaches in patients with unexplained developmental delay or mental retardation. Am. J. Med. Genet. A. 140: 2063-2074. http://dx.doi.org/10.1002/ajmg.a.31416

Regier DA, Friedman JM and Marra CA (2010). Value for money? Array genomic hybridization for diagnostic testing for genetic causes of intellectual disability. Am. J. Hum. Genet. 86: 765-772. http://dx.doi.org/10.1016/j.ajhg.2010.03.009

Riggs ER, Wain KE, Riethmaier D, Smith-Packard B, et al. (2014). Chromosomal microarray impacts clinical management. Clin. Genet. 85: 147-153. http://dx.doi.org/10.1111/cge.12107

Ropers HH (2010). Genetics of early onset cognitive impairment. Annu. Rev. Genomics Hum. Genet. 11: 161-187. http://dx.doi. org/10.1146/annurev-genom-082509-141640

Rosa RF, Dibi RP, Picetti JdosS, Rosa RC, et al. (2008). [Amenorrhea and X chromosome abnormalities]. Rev. Bras. Ginecol. Obstet. 30: 511-517.

South ST and Brothman AR (2011). Clinical laboratory implementation of cytogenomic microarrays. Cytogenet. Genome Res. 135: 203-211. http://dx.doi.org/10.1159/000331425

Sowińska-Seidler A, Piwecka M, Olech E, Socha M, et al. (2015). Hyperosmia, ectrodactyly, mild intellectual disability, and other defects in a male patient with an X-linked partial microduplication and overexpression of the KAL1 gene. J. Appl. Genet. 56: 177-184. http://dx.doi.org/10.1007/s13353-014-0252-7

Stevens SJ, van Ravenswaaij-Arts CM, Janssen JW, Klein Wassink-Ruiter JS, et al. (2011). MYT1L is a candidate gene for intellectual disability in patients with 2p25.3 (2pter) deletions. Am. J. Med. Genet. A. 155A: 2739-2745. http://dx.doi. org/10.1002/ajmg.a.34274

Vissers LE, de Vries BB, Osoegawa K, Janssen IM, et al. (2003). Array-based comparative genomic hybridization for the genomewide detection of submicroscopic chromosomal abnormalities. Am. J. Hum. Genet. 73: 1261-1270. http://dx.doi. org/10.1086/379977

Wordsworth S, Buchanan J, Regan R, Davison V, et al. (2007). Diagnosing idiopathic learning disability: a cost-effectiveness analysis of microarray technology in the National Health Service of the United Kingdom. Genomic Med. 1: 35-45. http:// dx.doi.org/10.1007/s11568-007-9005-6

Zahir F and Friedman JM (2007). The impact of array genomic hybridization on mental retardation research: a review of current technologies and their clinical utility. Clin. Genet. 72: 271-287. http://dx.doi.org/10.1111/j.1399-0004.2007.00847.x 